\title{
Role of interleukin- 6 in mediating the acute phase protein response and potential as an early means of severity assessment in acute pancreatitis
}

\author{
D I Heath, A Cruickshank, M Gudgeon, A Jehanli, A Shenkin, C W Imrie
}

Departments of Surgery

D I Heath

C W Imrie

and Institute of Biochemistry, Glasgow A Cruickshank

A Shenkin

Department of Surgery, St George's Medical School, London.

$M$ Gudgeon

A Jehanli

Correspondence and requests for reprints to:

D I Heath, Department of

Surgery, Ward 36, Glasgow

Royal Infirmary, Glasgow G40SF.

Accepted for publication

8 June 1992 Royal Infirmary, Glasgow

\begin{abstract}
A number of laboratory and clinical studies have shown that interleukin-6 is the principal mediator of the acute phase protein response. In this study the relationship between serum concentrations of interleukin-6 and C-reactive protein in acute pancreatitis are examined and the ability of interleukin-6 to discriminate between severe and mild attacks is assessed. We have studied 24 patients (10 severe and 14 mild). Serum samples were collected on admission, six hourly for $\mathbf{4 8}$ hours and then 12 hourly for a further three days. When the areas under the curves of individual patients were compared there was a strong correlation between the total production of interleukin- 6 and $\mathrm{C}$-reactive protein $(\mathrm{r}=\mathbf{0 . 7 3 )}$ (Spearman rank correlation) and peak interleukin-6 and C-reactive protein concentrations $(r=0.75)$, suggesting a close relationship between interleukin-6 and C-reactive protein production. Both on admission and peak interleukin-6 concentrations were significantly higher in patients with severe than mild disease. There was no significant difference in on admission C-reactive protein concentrations, although significant differences were seen when peak concentrations were considered. Utilising a peak interleukin- 6 concentration of $>130 \mathrm{u} / \mathrm{ml}$, we were able to distinguish between severe and mild attacks of acute pancreatitis with a sensitivity of $100 \%$ and specificity of $71 \%$. These figures were comparable with those for peak $\mathrm{C}$-reactive protein, a C-reactive protein of
\end{abstract}

$>150 \mathrm{mg} / \mathrm{l}$ detecting severe attacks of acute pancreatitis with a sensitivity of $90 \%$ and specificity of $79 \%$. In view of the fact that interleukin-6 concentrations peaked earlier than those of $\mathrm{C}$-reactive protein, interleukin-6 is capable of providing comparable, but earlier severity prediction than C-reactive protein.

(Gut 1993; 34: 41-45)

Our inability to identify correctly severe acute pancreatitis on admission to hospital using clinical examination alone ${ }^{1-3}$ has led to the development of a number of more objective means of severity assessment. These include the Ranson $^{4}$ and Glasgow ${ }^{5}$ scoring systems, APACHE II scoring system ${ }^{36}$ and a variety of single factors measured in serum..$^{78}$ Recently the effectiveness of serum C-reactive protein concentration measurements in determining the severity of acute pancreatitis has been demonstrated. ${ }^{39-11}$ In common with the other methods described above, however, C-reactive protein measurements involve a delay of 48 hours or longer before prediction. One possible means of avoiding this delay is by measuring the serum concentrations of the principal mediator of the acute phase protein response: interleukin-6. ${ }^{12-14}$ In this study we examine the ability of interleukin- 6 to provide early severity prediction in acute pancreatitis and in addition examine the relationship between interleukin- 6 and the acute phase protein, C-reactive protein.

\section{Methods}

TABLE I The clinical details of 10 patients with severe and 14 with mild acute pancreatitis. $G S=$ gall stones. There are more complications than patients due to the fact that a patient may have more than 1 complication

\begin{tabular}{|c|c|c|c|}
\hline & $\begin{array}{l}\text { Severe } \\
\text { pancreatitis }\end{array}$ & $\begin{array}{l}\text { Mild } \\
\text { pancreatitis }\end{array}$ & Difference \\
\hline $\begin{array}{l}\text { Median age (years) } \\
\text { (range) }\end{array}$ & $\begin{array}{l}51 \cdot 5 \\
(23-69)\end{array}$ & $\begin{array}{l}44 \cdot 5 \\
(21-77)\end{array}$ & $\begin{array}{l}95 \% \mathrm{CI}=-13 \text { to } \\
20, \mathrm{p}<0.79\end{array}$ \\
\hline Ratio of sexes M:F & $8: 2$ & $11 \cdot 3$ & $N S p<0.67$ \\
\hline \multicolumn{4}{|l|}{ Aetiology of attack } \\
\hline Alcohol & 6 & 6 & NS $p<0 \cdot 3$ \\
\hline Gall stones & 3 & 7 & \\
\hline Unknown & 1 & 1 & \\
\hline \multicolumn{4}{|l|}{ Median hospital stay } \\
\hline $\begin{array}{l}\text { (days) } \\
\text { (range) }\end{array}$ & $\begin{array}{l}19 \\
(7-25)\end{array}$ & $\begin{array}{l}7 \cdot 5 \\
(6-22)\end{array}$ & $\begin{array}{l}95 \% \mathrm{CI}=9 \cdot 6 \text { to } 1 \\
\mathrm{p}<0.001\end{array}$ \\
\hline \multicolumn{4}{|l|}{ Complications } \\
\hline Respiratory failure & 2 & 0 & - \\
\hline Renal failure & 1 & 0 & - \\
\hline Hospital stay $<14$ days & 5 & 0 & - \\
\hline Pancreatic pseudocyst & 4 & 0 & - \\
\hline
\end{tabular}

$\mathrm{CI}=$ confidence interval, $\mathrm{NS}=$ not significant.
PATIENTS

Twenty four patients with acute pancreatitis were prospectively entered into the study between December 1987 and July 1989. The diagnosis of acute pancreatitis was made on the basis of a serum amylase greater than $720 \mathrm{IU} / \mathrm{l}$ in the presence of a compatible clinical picture of the disease (a value of $720 \mathrm{IU} / 1$ being equivalent to a value of $1200 \mathrm{IU} / 1$ as measured by the Phadebas method). The clinical and aetiological details of the 24 patients entered into the study (14 mild and 10 severe) are summarised in Table I. The groups were comparable in terms of age, sex, and aetiology with hospital stay being significantly longer in patients with severe disease. 
SPECIMEN HANDLING AND ANALYSIS

Samples of blood were taken at the time of admission, six hourly for 48 hours and then twice daily for a further three days. Specimens were centrifuged, separated, aliquoted, and stored at $-20^{\circ} \mathrm{C}$ before analysis for C-reactive protein, and interleukin-6.

Measurements of serum amylase concentrations were made on a Hitachi 737 random access discrete analyser (Boehringer Mannheim, Germany) using an enzymatic colorimetric assay ( $\alpha$ amylase PNP (Boehringer Mannheim, Germany)). C-reactive protein concentrations (normal $<10 \mathrm{mg} / \mathrm{l}$ ) were measured using a competitive binding, fluorescence polarisation immunoassay (TDX reagents and analyser, Abbott Diagnostic, England). Interleukin-6 concentrations were measured using the interleukin-6 dependent 7TD1 cell line, ${ }^{15}$ the rate of growth of which was calculated using a colorimetric substrate (a tetrazolium salt which was cleaved by dehydrogenase enzymes present in living cells). ${ }^{16}$ Standardisation was performed using recombinant interleukin $-6^{17}$ which had been assigned a specific activity of $10^{6}$ units per microgram - that is, 1 picogram of interleukin- 6 was equivalent to $1 \mathrm{u}$. A normal serum interleukin-6 concentration was $<10 \mathrm{u} / \mathrm{ml}$.

\section{DISEASE SEVERITY}

Disease severity was graded retrospectively depending upon the clinical outcome. Patients were considered to have suffered a severe attack of acute pancreatitis if they developed one or more of the following: a pancreatic pseudocyst; pancreatic sepsis; respiratory failure (as judged by a $\mathrm{pO}_{2}<8 \mathrm{~K}$ Pa requiring oxygen for $>$ five days or assisted ventilation); renal failure (as evidenced by $<400 \mathrm{ml}$ urine per 24 hours after adequate fluid replacement); shock (defined as a systolic

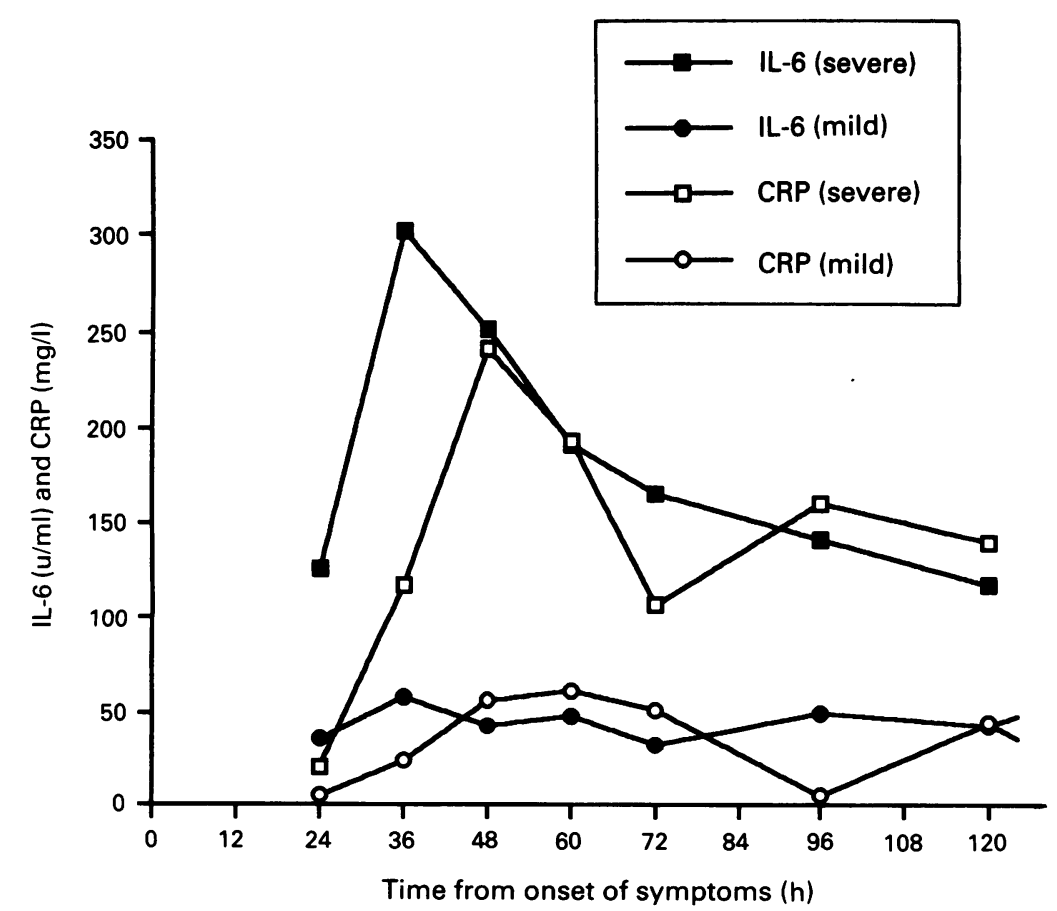

Figure 1 Median interleukin-6 and C-reactive protein concentrations in the serum of 10 patients with severe and 14 with mild acute pancreatitis. blood pressure $<90 \mathrm{~mm}$ of $\mathrm{Hg}$ in the presence of an adequate circulating fluid volume); a hospital stay of $>14$ days (except where discharge was. delayed for cholecystectomy or social reasons); or death. Where none of the above was present the patient was considered to have suffered a mild attack.

\section{DATA ANALYSIS}

In order to examine the time course of interleukin-6 and C-reactive protein production in patients with acute pancreatitis, it was necessary to correlate serum concentrations from the time of onset of symptoms rather than from the time of admission. As it was not possible to control the delay between the onset of symptoms and admission to hospital, it was not possible to obtain samples at exactly corresponding tissue points from different patients. Samples were therefore allocated to one of eight groups. These were $<24$ hours, 25-36 hours, 37-48 hours, 49-60 hours, 61-72 hours, 73-96 hours, 97-120 hours and $>121$ hours representing the range of times between the onset of symptoms and the sample being taken.

Data were analysed using medians, the Mann Whitney U test, Fisher's exact test and the Spearman rank correlation test as appropriate. Confidence intervals were used in preference to $p$ values in judging the relevance of differences. ${ }^{18}$

The area under the curve of interleukin -6 and C-reactive protein represents the magnitude of the response during the study period. The areas under curves (AUC) were calculated from the formula:-

$$
A U C=\frac{1}{2} \sum_{i=0}^{n-1}\left(t_{i+1}-t_{i}\right)\left(y_{i}+y_{i+1}\right)
$$

Where $t=$ the time after admission, $y=$ the concentration at time $t, i=$ initial time points and $\mathrm{n}$ represents the last time point.

The areas under the curves were divided by the number of hours in order to take account of the different times for which samples had been collected from individual patients.

\section{Results}

Serum concentrations of interleukin- 6 rose during the first 24 hours after the onset of symptoms in all patients and peaked between 24 and 36 hours (Fig 1). The magnitude of the interleukin- 6 response (represented by the area under the response curve) differed between patient groups. In patients with severe disease the median response was $240 \mathrm{u} / \mathrm{ml} / \mathrm{h}$ (range $72-$ $560 \mathrm{u} / \mathrm{ml} / \mathrm{h}$ ) and in the mild group $38 \mathrm{u} / \mathrm{ml} / \mathrm{h}$ (range 18-140 $\mathrm{u} / \mathrm{ml} / \mathrm{h}$ ). These differences were highly significant $(95 \%$ confidence interval $(\mathrm{CI})=92$ to $232 \mathrm{u} / \mathrm{ml} / \mathrm{h}, \mathrm{p}<0.001$ ). Peak interleukin- 6 concentrations correlated well with the magnitude of the interleukin- 6 response $(r=0.94)$ and can therefore be considered to represent accurately the overall response.

C-reactive protein concentrations rose during the first 24 hours to peak between 36 and 48 hours after the onset of symptoms (Fig 1). The magnitude of the $\mathrm{C}$-reactive protein response 


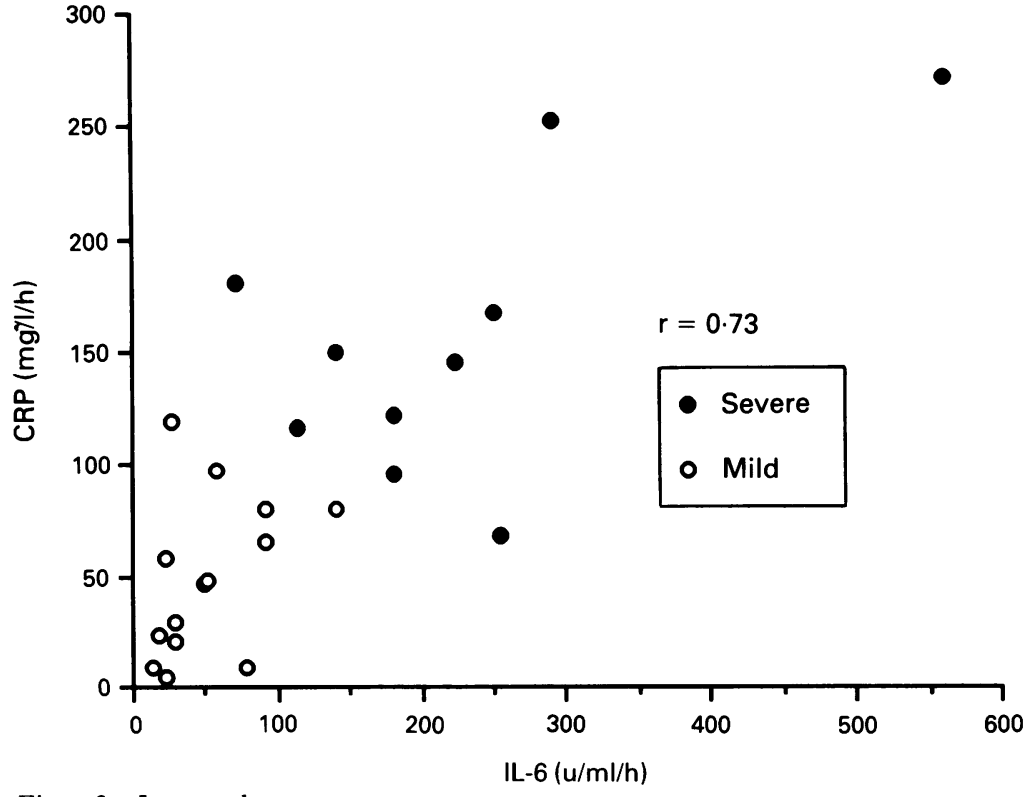

Figure 2 Integrated interleukin-6 and C-reactive protein response in 10 patients with severe and 14 with mild acute pancreatitis.

Figure 3 Peak serum interleukin-6 and $C$-reactive protein concentrations in 10 patients with severe and 14 with mild acute pancreatitis.

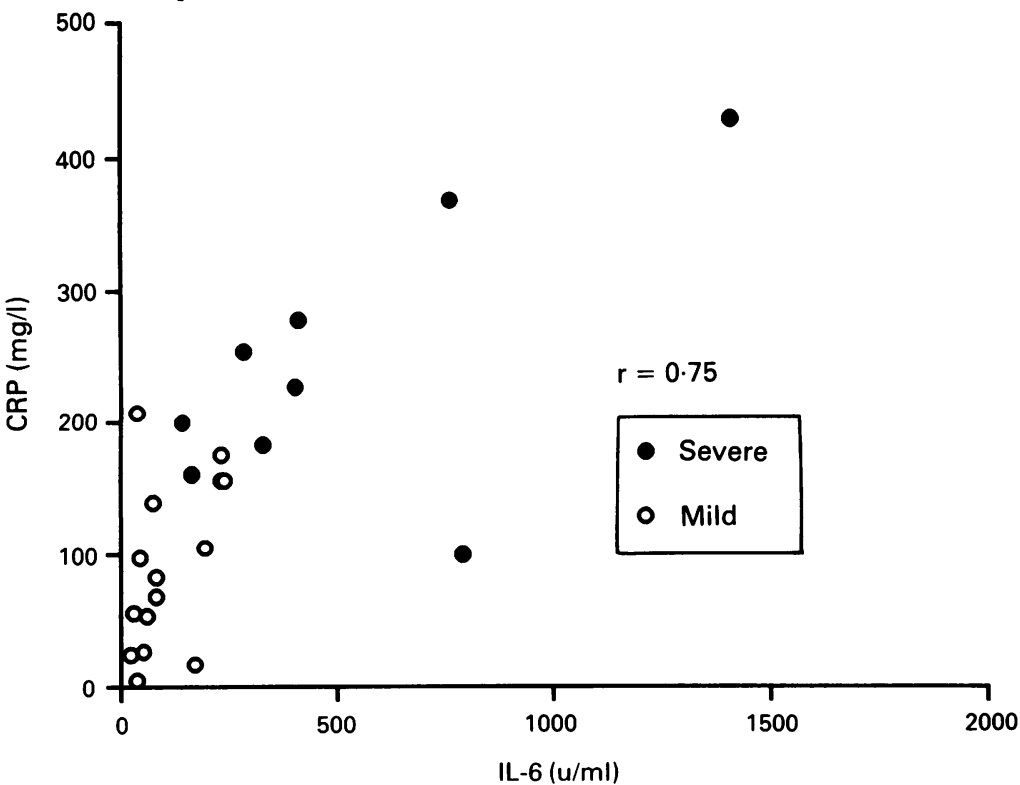

noted when peak concentrations were considered (95\% CI=74 to $214 \mathrm{mg} / \mathrm{l}, \mathrm{p}<0.0006)$. The sensitivity, specificity, positive and negative predictive values and percentage correct for a peak interleukin- 6 concentration of $>130 \mathrm{u} / \mathrm{ml}$ and a C-reactive protein concentration of $>150$ $\mathrm{mg} / \mathrm{l}$ are displayed in Table II.

\section{Discussion}

Experimental studies conducted in animals, hepatoma cell lines, and normal human hepatocyte cultures have shown that interleukin- 6 is the principal mediator of the acute phase protein response of which C-reactive protein is an important component. ${ }^{12-14}$

In the present study the median delay between the onset of symptoms and peak interleukin- 6 concentrations was between 24 and 36 hours and is in agreement with the clinical studies of Van Oers et $a l^{19}$ but is somewhat longer than those of Nijsten $e t a l,{ }^{20}$ Shenkin $e t a l^{21}$ and Cruickshank et $a l^{22}$ Van Oers et $a l^{19}$ noted peak serum interleukin- 6 concentrations on the second day post renal transplantation (presumed delay between transplantation and the measurement of interleukin- 6 concentration $36-48$ hours) and Nijsten et $a l^{20}$ noted peak concentrations on admission in burns patients (presumed delay $<$ six hours). Shenkin $e t a l^{21}$ noted peak concentrations of interleukin- 6 between 1.5 and four hours after the skin incision was made in a group of patients undergoing elective cholecystectomy and Cruickshank et $a l^{22}$ six to 12 hours after the skin incision for a variety of surgical procedures. As Nijsten $e a^{20}$ tell us little about the severity of the burns (if patients had only mild burns the peak interleukin- 6 concentration would be small and short lived) and only took samples on a daily basis, it is probable that peak interleukin-6 concentrations have been missed. Further evidence that peak interleukin- 6 concentrations may occur later in inflammatory disease comes from animal work. Geiger et $a l^{23}$ injected one group of rats with human recombinant interleukin- 6 and one with turpentine (a means of inducing an acute inflammatory reaction) and then compared the time to maximal mRNA production for a number of acute phase proteins. In those injected with interleukin- 6 peak concentrations of acute phase protein mRNAs were seen within four hours, whereas there was a delay of 16-24 hours in those injected with turpentine. While peak mRNA concentrations will precede those of the proteins for which they code these findings are in better agreement with those of the present study and of Van Oers et al's' ${ }^{19}$ than of Nijsten $e t a l{ }^{\prime 20}$ and the other workers quoted above. On the basis of this and the studies quoted above the timing of peak interleukin- 6 concentrations appears to be somewhat variable. The late peaks probably relate to a continuing inflammatory process, in contrast with operative trauma which was short lived.

Of more importance than the exact time of peak interleukin- 6 concentrations is the relationship between peak interleukin-6 and C-reactive protein concentrations. In the present study the delay to peak $\mathrm{C}$-reactive protein concentrations was 36 to 48 hours. In Nijsten et al's ${ }^{20}$ study 
TABLE II Sensitivity, specificity, positive predictive value, negative predictive value and percentage correct for serum concentrations of interleukin-6 and $C$-reactive protein in seventy predictions in acute pancreatitis

\begin{tabular}{lccccc}
\hline & $\begin{array}{l}\text { Sensitivity } \\
\%\end{array}$ & $\begin{array}{l}\text { Specificity } \\
\%\end{array}$ & $\begin{array}{l}\text { Positive } \\
\text { predictive } \\
\text { value \% }\end{array}$ & $\begin{array}{l}\text { Negative } \\
\text { predictive } \\
\text { value \% }\end{array}$ & \% Correct \\
\hline $\begin{array}{l}\text { Admission interleukin-6 } \\
\begin{array}{l}>120 \text { IU/ml } \\
\text { Admission C-reactive protein }\end{array}\end{array}$ & 70 & 79 & 88 & 79 & 75 \\
$\begin{array}{l}>120 \mathrm{mg} / \mathrm{l} \\
\text { Peak interleukin-6 }\end{array}$ & 30 & 100 & 100 & 59 & 54 \\
$\begin{array}{l}\text { >130 IU/ml } \\
\text { Peak C-reactive protein }\end{array}$ & 100 & 71 & 71 & 100 & 83 \\
$\begin{array}{l}>150 \mathrm{mg} / \mathrm{l} \\
\text { Glasgow score }>2\end{array}$ & 90 & 79 & 75 & 92 & 83 \\
\hline
\end{tabular}

peak C-reactive protein concentrations were noted on the first post admission day (presumed delay between interleukin-6 and C-reactive protein peak 24 hours) and are in keeping with the results for this study population. Similar results were achieved by Shenkin et $a l^{21}$ who noted peak C-reactive protein concentrations between 36 and 48 hours and Cruickshank et al ${ }^{22}$ who noted peak C-reactive protein concentrations between 24 and 48 hours. These results are also in keeping with the findings of laboratory based studies. The addition of human recombinant interleukin-6 to hepatoma cell lines has been shown to produce a maximal acute phase protein response between 20 and 36 hours. ${ }^{24} 25$ When interleukin-6 was added to adult rat hepatocyte cultures the delay was 24 hours $^{26}$ and when injected into rats 16-24 hours. ${ }^{23}$ The delay to peak C-reactive protein concentrations in patient with acute pancreatitis in the present study are in agreement with the work of the group from Leeds 9 and our own previous study. ${ }^{3}$ Both Buchler et $a l^{11}$ and Poulakkainen et al, ${ }^{10}$ however, reported peak C-reactive protein concentrations at the time of admission. Many of their referrals were tertiary and probably had already undergone a delay of 48 hours or longer before C-reactive protein measurements.

The significant correlation noted between the integrated interleukin- 6 and $C$-reactive protein responses $(r=0.73)$ and between peak interleukin-6 and C-reactive protein concentrations $(r=0.75)$, coupled with the fact that the median peak interleukin-6 concentrations preceded those of $\mathrm{C}$-reactive protein provides support for the hypothesis that interleukin-6 is acting as a mediator of C-reactive protein production. Interleukin-6 may not be the only mediator of the acute phase protein response, however. When Morrone et $a l^{27}$ added recombinant interleukin-6 to Hep $3 B$ cell line they were able to induce partially the gene governing C-reactive protein production. Complete induction was only achieved when monocyte supernatant was added as well. Baumann et $a l^{28}$ have demonstrated that the optimal acute phase protein response in Hep G2 human hepatoma cell lines is only produced in the presence of interleukin-1 and dexamethasone and both Castell et $a l^{131+}$ and Moshag et $a l^{12}$ have demonstrated that interleukin-1 augments the action of interleukin-6 in producing C-reactive protein in human hepatocyte cultures. It therefore seems likely that at least one of the factors inducing $\mathrm{C}$-reactive protein production in
Morrone et al's monocyte supernatant was interleukin-1. ${ }^{27}$

C-reactive protein has been widely adopted as a non-specific indicator of inflammation because serum concentrations rise more rapidly and to a greater degree than any other acute phase protein. Its usefulness in this role has been shown in medical $^{29}$ and surgical ${ }^{30}$ conditions, including acute pancreatitis. ${ }^{39-11}$ It does, however, have a major drawback in that it entails a similar delay to the other methods of severity assessment in acute pancreatitis. ${ }^{391011}$ The measurement of interleukin- 6 concentrations may overcome this problem and facilitate earlier severity prediction. Serum interleukin-6 concentrations rose more rapidly than those of $\mathrm{C}$-reactive protein. This earlier rise in interleukin-6 concentrations resulted in significant differences in on-admission interleukin- 6 concentrations between patients, an on admission serum concentration $>120 \mathrm{u} / \mathrm{ml}$ separated severe and mild attacks with a sensitivity of $70 \%$ and specificity of $79 \%$. These figures are comparable with figures previously reported for the multifactorial scoring systems and provide clinically useful separation between patient groups. ${ }^{+5}$ Such differences were not seen for serum C-reactive protein on admission, a serum concentration of $>120 \mathrm{mg} / \mathrm{l}$ being unable to distinguish effectively between patient groups. These findings are in agreement with the studies of Mayer ${ }^{9}$ and Wilson et al,${ }^{6}$ as discussed above. Better separation between the patient groups was noted when peak concentrations were considered, the sensitivity and specificity of interleukin-6 and C-reactive protein being comparable, and somewhat better than previous reports of the mutlifactorial scoring systems. ${ }^{45}$

Speculation that interleukin-6 may be useful in clinical practice as a severity indicator in acute pancreatitis is dependent on results being available within a few hours of sample collection. The major drawback of the interleukin- 6 bioassay used here is the long turn around time of five days. Several commercial manufacturers, however, have recently developed and marketed immunoassays for interleukin-6 (Quantikine Human interleukin-6, British Bio-technology Ltd, Abingdon, Oxon; Biokine interleukin-6 test kit, T Cell Sciences, Cambridge; Co-eliza interleukin-6, Kabi Diagnostica, Sweden). These assays have turnaround times of less than six hours and consequently, the methodology is now available to produce interleukin- 6 results within the time scale necessary for them to be of value clinically. It should be noted, however, that we have no direct experience of any of these assays.

We would like to thank Dr J Van Snick for providing 7TD1 cell line and Dr L Aarden for providing recombinant interleukin-6.

1 McMahon MJ, Playforth MJ, Pickford IR. A comparative study of methods for the prediction of severity of attacks of acute pancreatitis. Br F Surg 1980; 67: 22-5.

2 Larvin M, McMahon MJ. APACHE-II score for assessment and monitoring of acute pancreatitis. Lancet 1989, ii: 201-5.

3 Wilson C, Heads A, Shenkin A, Imrie CW. C-reactive protein, antiproteases and complement factors as objective markert of severity in acute pancreatitis. Br F Surg 1989; 76: 177-81. 4 Ranson JHC, Rifkind KM, Roses DF, Fink SD, Eng K, Spencer FC. Prognostic signs and the role of operative management in acute pancreatitis. Surg Gynecol Obstet 1974 . 139: 69-81.

5 Imrie CW, Benjamin IS, Ferguson IC, McKav AI, Macken $\%$ ie 
I, O'Neill T, et al. A single-centre double-blind trial of Trasylol therapy in primary acute pancreatitis. Br $\mathcal{F}$ Surg

1978; 65: $337-41$.
6 Wilson C, Heath DI, Imrie CW. Prediction of outcome in acute pancreatitis: a comparative study of APACHE II, clinical assessment and multiple factor scoring systems. $\mathrm{BrF}$ Surg 1990; 77: 1260-4.

7 Berry AR, Taylor TV, Davies GC. Pulmonary function and fibrinogen metabolism in acute pancreatitis. Br $\mathcal{F}$ Surg 1981 68: $870-3$.

8 McMahon MJ, Bowen M, Mayer AD, Cooper EH. Relationship of $\alpha 2$-macroglobulin and other antiproteases to the clinical features of acute pancreatitis. Am $\mathcal{F}$ Surg 1984; 147: 164-70.

9 Mayer AD, McMahon MJ, Bowen M, Cooper EH. C reactive protein: an aid to assessment and monitoring of acute protein: an aid to assessment and moni

10 Puolakkainen P, Valtonen V, Paananen A, Schroder T. $\mathrm{C}$-reactive protein (CRP) and serum phospholipase $\mathrm{A}_{2}$ in the assessment of the severity of acute pancreatitis. Gut 1987 28: 764-71.

11 Buchler M, Malfertheiner P, Beger HG. Correlation of imaging procedures, biochemical parameters and clinical stage in acute pancreatitis. In: Malfertheiner $P$, Ditschuneit $\mathrm{H}$ eds. Diagnostic procedures in pancreatic disease. Berlin: Springer Verlag, 1986: 123-9.

12 Moshage HJ, Roelofs HMJ, Van Pelt JF, Hazenberg BPC Van Leeuwen MA, Limburg PC, et al. The effect of interleukin-1, interleukin- 6 and its interrelationship on the synthesis of serum and amyloid A and C-reactive protein in pynthesis of serum and amyloid $\mathrm{A}$ and $\mathrm{C}$-reactive protein in primary cultures of adult human hepa
Biophys Res Commun 1988; 155: 112-7.

13 Castell JV, Gomez-Lechon MJ, David M, Hirano T, Kishimoto T, Heinrich PC. Recombinant human interleukin-6 (IL-6/ BSF-2/HSF) regulates the synthesis of acute phase protein in human hepatocytes. FE BS Lett 1988; 232: 347-50.

14 Castell JV, Gomez-Lechon MJ, David M, Andus T, Geiger T, Trullenque $\mathrm{R}$, et al. Interleukin-6 is the major regulator of acute phase protein synthesis in adult human hepatocytes. FEBS Lett 1989; 242: 237-9.

15 Coulie PG, Cayphas S, Vink A, Uyttenhove C, Van Snick J. Interleukin-HPl-related hybridoma and plasmacytoma growth factors induced by lipopolysaccharide in vivo. Eurf Immunol 1987; 17: 1217-220.

16 Mosmann T. Rapid colorimetric assay for cellular growth and survival: application to proliferation and cytotoxicity assays. 7 Immunol Methods 1983; 65: 55-63.

17 Brackenhoff LPJ, De Groot ER, Evers RF, Pannekoek H, Aarden LA. Molecular cloning and expression of hybridoma growth factor in $E$ coli 7 Immunol 1987 ; 139: 4116-21.

18 Gardner MJ, Altman DG. Statistics with confidence - confidence intervals and statistical guidelines. London: BMJ Publications, 1989

19 Van Oers MHJ, Van Der Heyden AAPM, Aarden LA Interleukin-6 (IL-6) in serum and urine or renal transplant recipients. Clin Exp Immunol 1988; 71: 314-9.

20 Nijsten MWN, De Groot ER, Ten Duis HJ, Klasen JH, Hack HJ, Aarden LA. Serum levels of interleukin-6 and acute phase responses. Lancet 1987 i: 921

21 Shenkin A, Fraser WD, Series J, Winstanley FP, McCartney AC, Burns HJG, et al. The serum interleukin 6 response to elective surgery. Lymphokine Res 1989; 8: 123-7.

22 Cruickshank AM, Fraser WD, Burns HJG, Van Damme J, Shenkin A. Response of serum interleukin-6 in patients undergoing elective surgery of varying severity. Clin $S_{c i}$ undergoing elective

23 Geiger T, Andus T, Klapproth J, Hirano T, Kishimoto T, Heinrich PC. Induction of rat acute phase proteins by interleukin-6 in vivo. $\mathcal{F}$ Biol Chem 1988; 263: 71416

24 Ritchie DG, Fuller GM. Hepatocyte stimulating factor: a monocyte derived acute phase regulatory protein. Ann NY Acad Sci 1983; 408: 490-502.

25 Baumann H, Muller-Eberhard U. Synthesis of haemopexin and cysteine protease inhibitor is coordinately regulated by HSF-II and interferon- $\beta 2$ in rat hepatoma cells. Biochem Biophys Res Commun 1987; 146: 1218-26.

26 Andus T, Geiger T, Hirano T, Kishimoto T, Tran-Thi TA, Decker $\mathrm{K}$, et al. Regulation of synthesis and secretion of major rat acute-phase proteins by recombinant human major rat acute-phase proteins by recombinant human Eur F Biochem 1988; 173: 287-93.

27 Morrone G, Ciliberto G, Oliviero S, Arcone R, Dente L, Content $\mathrm{J}$, et al. Recombinant interleukin-6 regulates the transcriptional activation of a set of human acute phase genes. F Biol Chem 1988; 263: 2554-8.

28 Baumann H, Richards C, Gauldie J. Interaction among hepatocyte stimulating factors, interleukin-1 and glucocorticoids for regulation of acute phase plasma proteins in human hepatoma (Hep G2) cells. F Immunol 1987; 139: $4122-8$.

29 Amos RS, Constable TJ, Crockson RA, McKonkey B. Rheumatoid arthritis: relation of serum C-reactive protein and erythrocyte sedimentation rates to radiographic changes. and erythrocyte sedim

30 Mustard RA, Bohnen MA, Haseeb S, Kasina R. C-reactive protein levels predict post-operative septic complications. Arch Surg 1987; 122: 69-73. 